Discussion Paper No. 08-126

\title{
Endogenous Firm Heterogeneity, ICT and R\&D Incentives
}

Daniel Cerquera and Gordon J. Klein

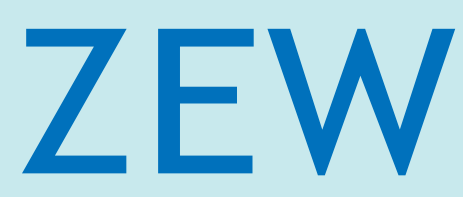

Zentrum für Europäische Wirtschaftsforschung $\mathrm{GmbH}$

Centre for European

Economic Research 
Discussion Paper No. 08-126

\title{
Endogenous Firm Heterogeneity, ICT and R\&D Incentives
}

\author{
Daniel Cerquera and Gordon J. Klein
}

Download this ZEW Discussion Paper from our ftp server:

ftp://ftp.zew.de/pub/zew-docs/dp/dp08126.pdf

Die Discussion Papers dienen einer möglichst schnellen Verbreitung von neueren Forschungsarbeiten des ZEW. Die Beiträge liegen in alleiniger Verantwortung der Autoren und stellen nicht notwendigerweise die Meinung des ZEW dar.

Discussion Papers are intended to make results of ZEW research promptly available to other economists in order to encourage discussion and suggestions for revisions. The authors are solely responsible for the contents which do not necessarily represent the opinion of the ZEW. 


\section{Non-technical summary}

The economic literature has provided robust evidence indicating that the adoption of information and communication technologies (ICT) has positively affected productivity at aggregate and firm levels. Given the rapid technological progress observed in the production of ICT and the uncertainty and costs associated with their implementation, it is not surprising that the benefits of ICT are not equally distributed among adopting firms. As some firms reap those benefits sooner and better than others, the adoption of ICT represents a source of firm heterogeneity that might generate competitive advantages and affect firm strategies.

This paper studies how the adoption of ICT affects firm heterogeneity and how such (ICT induced) heterogeneity impacts R\&D incentives. The analysis is based on two established results from the empirical literature on the analysis of productivity at the firm level. First, there exist high and persistent productivity differences within industries (i.e. firm heterogeneity) and those differences explain the process of creative destruction: more productive firms grow faster, exhibit a higher probability of survival and displace low productivity firms. Second, the adoption of ICT has a significant, positive impact on productivity at the firm level. This paper attempts to uncover the role of ICT in generating firm heterogeneity and thereby contributing to the process of creative destruction.

The analysis is carried out in two steps. In the first step, the impact of ICT on firm heterogeneity is estimated. Following existing literature, firm heterogeneity is defined as the deviation of a firm's productivity level from a given industry benchmark. Given that firm heterogeneity explains the productivity driven selection mechanism in which less productive firms are displaced by their more productive counterparts, the second stage estimates the impact of ICT induced heterogeneity on firms' R\&D incentives, as strategies that determine firm survival.

The results show that ICT has a robust, positive impact on firm heterogeneity only when ICT is used intensively and jointly with specific ICT applications. That is, through their use of ICT, firms are able to differentiate themselves (positively and negatively) with respect to other firms belonging to the same economic sector. The analysis also shows that ICT induced heterogeneity is not innocuous: it has a significant and positive, albeit small, impact on the incentives to innovate. In particular, ICT induced heterogeneity is shown to positively affect the decision to invest in R\&D personnel. 


\section{Das Wichtigste in Kürze}

Wie die wirtschaftswissenschaftliche Literatur zeigt, wirkt sich die Einführung von Informationsund Kommunikationstechnologien (IKT) sowohl auf die Produktivität auf Firmenebene als auch auf die aggregierte Produktivität positiv aus. Aufgrund des schnellen technologischen Fortschritts, der bei der Herstellung von IKT zu beobachten ist, sowie aufgrund der Unsicherheit und der Kosten, die mit der Implementierung verbunden sind, profitieren nicht alle Firmen gleichermaßen von IKT. Die Einführung von IKT ist deshalb eine Ursache für firmenspezifische Heterogenität, die wiederum Wettbewerbsvorteile erzeugt and somit Firmenstrategien beeinflusst.

Diese Studie untersucht, wie die Einführung von IKT die firmenspezifische Heterogenität bestimmt und wie diese IKT-induzierte Heterogenität die Firmenstrategien beeinflusst. Die Analyse basiert auf zwei grundlegenden Ergebnissen der empirischen Literatur zur Produktivität auf Firmenebene. Erstens gibt es große und dauerhafte Produktivitätsunterschiede innerhalb der Sektoren (d.h. firmenspezifische Heterogenität). Diese Unterschiede erklären den Prozess der kreativen Zerstörung: Produktivere Firmen wachsen schneller, haben eine größere Überlebenswahrscheinlichkeit und ersetzen die unproduktiven Firmen. Zweitens hat die Einführung von IKT einen positiven Einfluss auf die Produktivität auf Firmenebene.

Die Analyse besteht aus zwei Schritten: In einem ersten Schritt wird der Einfluss von IKT auf die firmenspezifische Heterogenität geschätzt. In Anlehnung an die bestehende Literatur wird diese firmenspezifische Heterogenität als Abweichung der Firmenproduktivität von einem branchenspezifischen Benchmark definiert. Im zweiten Schritt wird der Einfluss untersucht, den diese IKT-basierte Heterogenität auf die Innovationsanreize der Firmen hat.

Die Ergebnisse zeigen, dass IKT nur dann einen robusten, signifikanten Einfluss auf die firmenspezifische Heterogenität haben, wenn IKT intensiv und in Form spezifischer IKTAnwendungen genutzt werden. Dies bedeutet, dass sich Firmen durch ihre IKT-Nutzung von anderen Firmen der gleichen Branche (positiv wie negativ) unterscheiden können. Die IKTinduzierte Heterogenität wiederum hat einen positiven und signifikanten, wenngleich auch kleinen, Einfluss auf die Entscheidung, in F\&E-Personal zu investieren. 


\title{
Endogenous Firm Heterogeneity, ICT and R\&D Incentives*
}

\author{
Daniel CERQUERA ${ }^{\dagger}$ \\ Gordon J. KLEIN $\ddagger$ \\ ZEW Mannheim \\ Germany
}

December 29, 2008

\begin{abstract}
Firm heterogeneity explains the productivity driven selection mechanism that determines aggregate productivity growth within industries. This paper empirically demonstrates that ICT has a robust impact on firm heterogeneity only when ICT is used intensively and jointly with specific ICT applications. ICT induced heterogeneity is shown to have a positive impact on the decision to invest in $\mathrm{R} \& \mathrm{D}$ personnel.
\end{abstract}

Keywords: Firm Heterogeneity, Information and Communication Technologies, Creative Destruction, R\&D Incentives, Firm Level Data.

JEL Classification: D21, L25, O32.

${ }^{*}$ We would like to thank Irene Bertschek for valuable comments. We also gratefully acknowledge the comments and suggestions from participants at the 30th Hohenheimer Oberseminar at the University of Nuremberg 2008, the EU KLEMS Final Conference at the Universtiy of Groningen 2008 and the 35th Conference of the European Association of Research in Industrial Economics (EARIE), Toulouse 2008. All errors are ours.

${ }^{\dagger}$ cerquera@zew.de. Centre for European Economic Research (ZEW), Mannheim, Germany. Research Group Information and Communication Technologies. Corresponding author.

${ }^{\ddagger}$ klein@zew.de. Centre for European Economic Research (ZEW), Mannheim, Germany. Research Group Information and Communication Technologies. 


\section{Introduction}

The economic literature has provided robust evidence indicating that the adoption of information and communication technologies (ICT) has positively affected productivity at aggregate and firm levels 1 Given the rapid technological progress observed in the production of ICT and the uncertainty and costs associated with their implementation, it is not surprising that the benefits of ICT are not equally distributed among adopting firms. As some firms reap those benefits sooner and better than others, the adoption of ICT represents a source of firm heterogeneity that might generate competitive advantages, affect firm strategies and/or influence aggregate productivity growth $2^{2}$

This paper empirically studies how the adoption of ICT affects firm heterogeneity and how such (ICT induced) heterogeneity impacts R\&D incentives. The analysis is based on two established results from the empirical literature on the analysis of productivity at the firm level. The first result shows that there exist high and persistent firm level productivity differences within industries (i.e. firm heterogeneity) ${ }^{3}$ Moreover, those differences explain the process of creative destruction where more productive firms grow faster, exhibit a higher probability of survival and displace low productivity firms 4 The second result in the literature has documented how the adoption of ICT has a significant, positive impact on productivity at the firm level:5 Although the latter suggests that ICT impacts firm heterogeneity, the main contribution of this paper is to account for the role of ICT on specific measures of firm heterogeneity.

If the adoption of ICT is expected to affect firm heterogeneity, and firm heterogeneity in turn explains the process of creative destruction within industries, then the estimated ICT induced heterogeneity should be also related to additional firm strategies relevant for firm survival. The present analysis empirically assess the impact of the recovered ICT induced heterogeneity on one of such strategies: firm specific R\&D incentives. Even though firm level competitiveness and survival depends on a wide range of factors, it has been widely recognized that innovative efforts are at the core of successful firm level strategies to tackle competition $\sqrt{6}$ In the literature, R\&D incentives are viewed as strategies that allow firms to differentiate themselves with respect to their competitors through their impact on firm

\footnotetext{
${ }^{1}$ See Draca et al. (2007), van Ark et al. (2008) and Jorgenson et al. (2008).

${ }^{2}$ See Chun et al. (2008).

${ }^{3}$ See Bartelsman and Doms (2000) for a survey.

${ }^{4}$ See Foster et al. (2008) for a discussion on the role of productivity on the process of creative destruction.

${ }^{5}$ See Draca et al. (2007) for a survey.

${ }^{6}$ See Aghion et al. (2005) and Aghion and Griffith (2005).
} 
level productivity $]^{7}$ This paper investigates whether R\&D incentives react to ICT induced heterogeneity.

The present analysis exploits a detailed database on the economic performance of a representative sample of the German manufacturing and service sector (ZEW ICT Survey). This data set contains information on the economic characteristics, performance, ICT use and innovative activity of the sampled firms for the years 2003 and 2006. ICT intensity is captured by the percentage of employees that work mainly with a PC (PCW). A set of dichotomous variables showing the adoption of different ICT applications such as enterprise resource planning systems (ERP), supply chain management (SCM) and customer relationship management software (CRM) is also available in the data. Additionally, the data include information on the innovative inputs (i.e. R\&D) and outputs (i.e. innovations introduced to the market) of the sampled firms.

Defining firm heterogeneity as the deviation of a firm's productivity level from a given industry benchmark, this paper shows that ICT has a robust, positive impact on firm heterogeneity only when ICT is used intensively and jointly with specific ICT applications. That is, through their use of ICT, firms are able to differentiate themselves (positively and negatively) with respect to other firms belonging to the same economic sector. This result is shown to be robust to different empirical strategies. In addition, the analysis also shows that ICT induced heterogeneity is not innocuous: it has a significant and positive, albeit small, impact on the incentives to innovate. In particular, ICT induced heterogeneity is shown to positively affect the decision to invest in $\mathrm{R} \& \mathrm{D}$ personnel.

The intuition behind this result states that firms are able to deviate from their competitors in terms of productivity and through ICT only when the adopted infrastructure is large enough (i.e. intensive use of PC accompanied by specific ICT applications). Given the costs and resources required for the adoption of such infrastructure, positive deviations result from the positive organizational impact of successful implementation of ICT (e.g. optimized internal processes), while negative deviations are associated with adoption costs that are not compensated by the benefits attached to the ICT infrastructure implemented (e.g. long term benefits not yet obtained). As firms in practice might employ several market strategies to differentiate themselves with respect to their competitors, it is not surprising that ICT induced heterogeneity is positively correlated with other market strategies such as R\&D investments.

\footnotetext{
${ }^{7}$ See Griliches (1995), Crepon et al. (1998) and Hall et al. (2008).
} 
The paper is organized as follows. The second section discusses related literature. The third section presents the details of the empirical strategy. The fourth section summarizes the main results of the paper. Finally, the fifth section concludes.

\section{Related Literature}

This paper is related with two strands of literature. First, there is a voluminous literature that documents the existence and persistence of firm heterogeneity in terms of productivity. This literature has been reviewed in Bertelsman and Doms (2000), and highlights the role of several supply-side production factors that determine productivity at the firm level. For instance, technology shocks, management skills, $R \& D$ investments, among others, are shown to affect firm level productivity in traditional production function estimation approaches.

In addition, Syverson (2004) studies the impact of demand-side factors that determine differences in observed productivity levels. In particular, he finds evidence of the negative impact of product substitutability within an industry on the dispersion of its productivity distribution. The lower the product substitutability within an industry, the more low productivity firms are able to stay in business and the higher the corresponding dispersion of the industry's productivity distribution.

This literature has also considered the role of ICT in determining firm level heterogeneity 8 In that literature, the estimated positive impact of ICT on productivity is recovered as the coefficient on a proxy for ICT capital from a production function estimation. That is, ICT is shown to increase the central tendency of the conditional productivity distribution but is silent about the effect of ICT on the dispersion of this distribution. Moreover, negative and positive impact of ICT are averaged out, making impossible to identify the potential negative impact of ICT and its consequences for firm strategies.

This paper presents a measure of firm heterogeneity that explicitly accounts for the dispersion of the productivity distribution, allowing the analysis of the role of ICT use on firm heterogeneity. In particular, firm heterogeneity is defined as the deviation of a firm's productivity level from a given industry benchmark. In consequence, the adopted measure exhibits two main advantages with respect to the existing literature. On the one hand, it permits to directly account for the role of ICT on firm heterogeneity in a way that cannot be inferred

\footnotetext{
${ }^{8}$ See Bresnahan et al. (2002), Brynjolfsson and Hitt (2003), and Bloom et al. (2008).
} 
from existing production function estimation. On the other hand, the economic literature has shown how firm heterogeneity (as previously defined) actually explains a great variety of strategic decisions at the firm level as the following literature review shows.

The second strand of literature related with the present paper analyzes the impact of firm heterogeneity on firm strategies. Although there is a voluminous literature in this area, the relevant work for the present paper corresponds to the analyses that considered similar measures of firm heterogeneity from an empirical perspective. For instance, firm decentralization decisions are theoretically and empirically explained by the role of firm heterogeneity (Acemoglu et al., 2007) and the nature of the relationship between innovation and competition depends on the level of firm heterogeneity (Aghion et al., 2005).

More specifically, defining the distance to the technological frontier as the difference between a firm's productivity level and the highest productivity level observed in the same industry (i.e. a measure of firm heterogeneity), Acemoglu et al. (2007) develop a model to analyze the relationship between the diffusion of new technologies and the decentralization of firms. They show, theoretically and empirically, that firms closer to the technological frontier are more likely to choose decentralization. The intuition behind this result states that these firms deal with newer technologies about which there is less information available. In consequence, a decentralized structure allows them to benefit from better informed managers (as opposed to principals).

In addition, and developing additional measures of firm heterogeneity, the paper shows how firms in more heterogeneous environments are also more likely to be decentralized because firm heterogeneity makes learning (i.e. how to exploit a new technology given the experience of others) more difficult. In a sequence of papers, Acemoglu et al. (2003), Aghion et al. (2005), Acemoglu et al. (2006) and Aghion et al. (2006) use similar measures of heterogeneity in order to study, among other topics, the relationship between innovation, entry, credit constraints and competition. Essentially, these papers highlight the role of firm heterogeneity as a main driver of industry evolution 9

In a different approach, Chun et al. (2008) directly estimate the impact of ICT use on firm heterogeneity for a panel of U.S. firms from 1971 to 2000. They find that elevated heterogeneity in firm performance (i.e. variability in labor productivity) is positively and significantly correlated with the use of ICT (i.e. ICT capital stock). The results also show that

\footnotetext{
${ }^{9}$ See Bartelsman et al. (2006) for an analysis of industry evolution using similar measures of firm heterogeneity.
} 
firm heterogeneity is associated with faster productivity growth. They argue that the results provide evidence of creative destruction (i.e. increased competition) at the firm level. That is, through their use of ICT, more productive firms displace less productive firms. However, their results can only be recovered at the industry level and do not permit the analysis of their impact on firm strategies. This paper contributes to this literature by explicitly considering the impact of ICT on productivity heterogeneity at the firm level, analyzing the consequences for specific firm strategies relevant to the process of creative destruction (i.e. $\mathrm{R} \& \mathrm{D}$ incentives).

\section{Empirical Analysis}

\subsection{Data}

The analysis is based on two waves of a business survey carried out by the Centre for European Economic Research (ZEW) corresponding to the years 2003 and 2006 (ZEW ICT Survey). The data set is a representative sample of the German manufacturing and service sector, and contains detailed information on the economic characteristics, performance and ICT use for 4,400 firms in each wave. Table 1 provides some descriptive statistics for the year 2003 . In general, and in line with similar data sets at the firm level, the surveyed firms evidence a great variability with respect to sales (in millions euros), number of employees and labor productivity calculated as the ratio between sales and number of employees. In addition, the empirical distribution of the reported sales, as well as the number of employees appear to be left skewed. The median size of the surveyed firm corresponds to 50 employees, whereas the average is about 337.7 employees. This indicates the presence of few very large companies in the data.

Analogously, the median value of sales is 7 millions with an average of 131.7 millions. The same also holds for the distribution of labor productivity where the median and the mean are 0.13 and 0.24 millions per employee, respectively. This skewness present in the distributions of the reported data is consistent with empirical analyses at the firm level. Table 1 also includes information about the use and intensity of ICT. The intensity in the use of ICT is measured by the percentage of employees working mainly with a $\mathrm{PC}(\mathrm{PCW})$ and is nearly equally distributed around the different percentiles. In addition, the data also provides information about different ICT software applications, namely enterprise resource planning (ERP), supply 
chain management (SCM) and customer relationship management (CRM).

Table 2 shows how the use of these different ICT applications are related with different firm characteristics. These firm characteristics (e.g. sales and number of employees) vary if the firm uses ICT more intense than the median (i.e. PCW greater than 50\%) or introduced ICT applications. Specifically, the table shows that the intense use of ICT, as well as the introduction of different ICT applications, is correlated with higher firm performance in terms of sales, number of employees and labor productivity. However, it should be noted that standard deviations are high through all the data, which indicates a high level of heterogeneity.

For example, the surveyed firms evidence 338 employees on average, whereas companies using ERP, SCM or CRM tend to be larger with 518, 518 and 627 average number of employees, respectively. The same can be observed in terms of sales. Firms using ICT applications or using ICT more intensively were more likely to exhibit higher sales. The average level of sales over all firms is 131.7 millions euros, whereas companies using CRM, SCM or ERP evidence 205.9, 222.8 and 209.2 millions, respectively. In general, these statistics show that firms using ICT more intensively tend to be larger than their counterparts.

Moreover, firms that use ICT more intensively and that introduce ICT applications do not only tend to be larger, but more efficient than other firms. In terms labor productivity (i.e. ratio between sales and number of employees), it can be seen that the average is 0.24 million euros per employee. This is higher for firms using ICT more extensively. Specifically, companies using ICT more intensively (i.e. PCW greater than 50\%) exhibit a labor productivity of 0.31 millions euro per employee. Moreover, companies using CRM exhibit on average 0.27 millions euro per employee, while those using SCM and ERP evidence 0.26 millions and 0.27 millions per employee, respectively.

In addition to these general characteristics, the data also contain information regarding the innovation activities of the sampled firms. For instance, as a proxy for innovation incentives, the data contain information on the fraction of employees working on R\&D activities in 2006 (i.e. R\&D intensity). The mean value of this variable is 0.17 with a median equal to 0.09 , indicating a left-skewed distribution.

In addition, information on innovation outputs is also available. This includes dummy variables indicating whether the firm introduced product or process innovations during the periods 2001-2003 and 2004-2006, the number of such innovation introduced during 2004-2006, the percentage of sales reported in 2006 that are derived from the product innovations in- 
troduced during the period 2004-2006 (mean: 26.32, median: 20) and the percentage of cost reductions achieved in 2006 from the introduction of process innovations during the period 2004-2006 (mean: 9.49, median: 8).

The measure of ICT intensity, percentage of employees working with a $\mathrm{PC}(\mathrm{PCW})$, is positively correlated to all measures of innovation. This does not hold for the ICT applications considered. For instance, ERP use is related to a slightly higher amount of the value of process innovations, while the value of product innovations slightly decreases from $27.4 \%$ to $25.8 \%$. The fraction of employees working on R\&D activities (i.e. R\&D intensity), however, is decreasing from $21.7 \%$ to $14.9 \%$ for firms that adopted ERP. This is different for the case of CRM use. The value of product innovations, the value of process innovations and $R \& D$ intensity are positively related with CRM adoption.

From the data set, the measure of firm heterogeneity at the firm level is constructed as the absolute value of the deviation of a given firm labor productivity, with respect to the median labor productivity in its corresponding industry. Deviations are taken in absolute values to derive a measure of heterogeneity associated with the dispersion of the productivity distribution. Labor productivity is computed as the ratio between sales and number of employees reported by the firms for a given year ${ }^{10}$

Note that by taking absolution values positive, as well as negative deviations are treated equally. Table 3 presents a quantile regression analysis of the firms' specific deviations (i.e. without taking absolute values) that further motivate the adopted measure of firm heterogeneity previously defined. The table shows that when used intensively, ICT induce positive deviations for quantiles above the median. That is, the marginal effect of ERP, conditional on high values of $\mathrm{PCW}$, is positive for quantiles above the median (i.e. columns 4-5), increasing the firm specific's deviation. In contrast, for quantiles below the median, ICT use reduces such deviation (i.e. column 2).

In addition to a positive correlation between productivity and ICT, there are also correlations between the intensity of ICT and firm heterogeneity. If firms use ICT intensively, they tend to deviate more from the median sector productivity (i.e. evidence more heterogeneity). Firm heterogeneity is also correlated to other firm characteristics. For instance, innovation tend to be positively correlated with firm heterogeneity.

\footnotetext{
${ }^{10}$ The sampled firms are classified into 14 industries. The banking and insurance sector was excluded from the analysis given the difficulties measuring sales. Firms with no obvious classification were also excluded.
} 


\subsection{Empirical Strategy}

As mentioned before, the measure of firm heterogeneity at the firm level is constructed as the absolute value of the deviation of a given firm labor productivity, with respect to the median labor productivity in its corresponding industry. Moreover, ICT intensity is captured by the percentage of employees that work mainly with a PC (PCW). A set of dichotomous variables showing the adoption of different ICT applications such as enterprise resource planning systems (ERP), supply chain management (SCM) and customer relationship management software $(\mathrm{CRM})$ is also available.

Additionally, the data includes information on the innovative inputs (i.e. R\&D) and outputs (i.e. innovations introduced to the market) of the sampled firms. In the present analysis, the fraction of total employees that is engaged in $R \& D$ activities is used as a measure of the incentives to invest in R\&D personnel (i.e. innovative activity). Additional general information at the firm and sectoral level is also included.

The empirical analysis follows a two stage strategy. In the first stage the direct effect of ICT on firm heterogeneity is estimated. This stage is implemented using OLS regressions, although the results are robust to different methods. In the second stage, the analysis follows an instrumental variables approach, where firm heterogeneity is instrumented by different measures of ICT use (providing a measure of ICT induced heterogeneity) and then related with the firms' R\&D incentives.

Equations (1) and (2) describe the general relationship between ICT, firm heterogeneity $(H)$ and innovation incentives $(I)$ and highlight the two stage instrumental variable strategy. The key identification assumption corresponds to the exclusion of ICT from equation (2). As discussed in the introduction, ICT generates firm heterogeneity, which in turn affect firm strategies. Therefore, it is assumed that ICT affects innovation incentives only through their impact on firm heterogeneity. Different statistical tests support this assumption.

$$
\begin{aligned}
H_{i, t} & =f\left(I C T_{i, t-1}, X_{i, t-1}\right) \\
I_{i, t} & =g\left(f_{i, t}, X_{i, t-1}\right)
\end{aligned}
$$

Specifically, $H_{i, t}$ is the measure of firm heterogeneity for firm $i$ in $t$, which corresponds to the 
year 2006. $I C T_{i, t-1}$ corresponds to the variables capturing the intensity of ICT use, as well as the adoption of ICT applications (i.e. ERP, SCM and CRM) with $t-1$ corresponding to the year 2003. $I_{i, t}$ represents firm $i$ 's innovation incentives captured by the fraction of total employees engaged in $\mathrm{R} \& \mathrm{D}$ activities. And $X_{i, t-1}$ is a matrix with control variables such as the economic sector a firm belongs to (14 classes), the geographic location of the firm (east or west Germany), as well as firm's age up to 2007, the presence of exporting activities in 2003, among others.

The analysis considers alternative functional forms for $f(\cdot)$ and $g(\cdot)$. In particular, the first stage assumes a linear specification for $f(\cdot)$ and the main results are presented in Table 4 . The results are robust to nonlinear considerations of $f(\cdot)$. In order to consider this possibility, a nonparametric analysis was performed. The analysis of the second stage also considered a linear specification for $g(\cdot)$. However, given the censoring present in the R\&D data available, a (nonlinear) Tobit model was also considered. In addition, in order to check the robustness of the results, an alternative semiparametric approach with a nonparametric first stage was also implemented (see Appendix A and B). The results of the second stage are presented in Table 5. Alternative robustness tests considering different samples (as it will be clear below), as well as different types of information regarding innovation activities were also performed.

\section{Results}

The analysis of the first stage is presented in Table 4. In particular, the objective of the first stage is to consider the relationship between the intensity of ICT use and firm heterogeneity, controlling for different firm characteristics that might influence such relationship. Table 4 present the analysis by means of ordinary least squares regression, which amount to assume a liner functional form for $f(\cdot)$ in equation (1). The results presented in Table 4 are robust to nonlinear considerations of $f(\cdot)$. In order to consider this possibility, a nonparametric analysis was performed.

In particular, the specification considered in column 1 of Table 4 estimates the direct impact of the intensity of ICT use in 2003 on the firm heterogeneity observed in 2006. The coefficient on ICT shows no impact on the observed firm heterogeneity, suggesting no independent impact of the intensity of ICT use. In order to account for the potential persistence in firm heterogeneity derived by the persistence in productivity differences, column 2 includes a set of dummy variables that locate each firm into the corresponding quartile of its sector specific 
productivity distribution. As can be observed, the result of column 1 is maintained with the specification presented in column 2 .

However, as highlighted by the economic literature, the adoption of ICT implies reorganization at the firm level in order to exploit the benefits of the ICT implementation. One dimension of potential complementary investments required to exploit the gains of ICT corresponds to the introduction of ICT (software) applications. By introducing specific ICT applications, a given firm might achieve a minimal ICT infrastructure needed to reap the benefits of the investments in computers and software.

In order to consider this possibility, the specification presented in column 3 includes specific ICT applications adopted by the sampled firms. In particular, EPR and SCM systems described previously are included. The hypothesis behind this specification states that the impact of ICT on firm heterogeneity does not only depend on the presence of ICT equipment, but also on the way such infrastructure is used. However, as the results shown in columns 1 and 2, the coefficients on ICT intensity and ICT applications show no independent impact on ICT on firm heterogeneity.

Column 4 extends the specifications presented in columns 1-3 to consider the interactions term between ICT and ERP. It analyzes whether the impact of ICT is associated with complementarities between the different ICT components. The results show positive and significant coefficients for the interaction term (coeff.: 0.19, std. error: 0.10), suggesting an important complementarity between the different components of the ICT infrastructure adopted at the firm level. That is, the impact of the intensity of ICT on firm heterogeneity is conditional on the presence of ERP systems. In other words, there is a critical infrastructure needed in order for ICT to differentiate a firm with respect to his competitors (i.e. induce firm heterogeneity). Note that if ICT is not used intensively, the marginal effect of the ERP applications on firm heterogeneity is negative because the independent impact of ERP is negative (coeff: -0.11 , std. error: 0.05).

Column 5 considers and alternative hypothesis to the one presented in column 4. In particular, it investigates the existence of complementarities in the introduction of ICT, but on different ICT applications. It considers the interaction term between PCW and SCM. As can be clear from the results presented in the table, the complementarity argument does not hold for this type of application. Moreover, additional results not reported in Table 4 show that the outcome of column 4 also extends to the consideration of the interaction term between PCW and CRM. 
This result is not surprising at least for two reasons. First, the ERP application is a generic general purpose software in comparison to the SCM and CRM applications. In consequence, the impact of SCM and CRM might be related with particular activities of the sampled firms that are not captured with the available data. These activities might be related with the firm specific relations with their suppliers or with costumers for the case of SCM and CRM, respectively. Second, SCM and CRM applications tend to be adopted by firms after a basic ICT infrastructure in general, and ERP systems in particular, are adopted successfully.

However, the data permit a testable hypothesis of the previous argument. That is, if there is any complementarity between ICT components that is related with their characteristics and/or timing of adoption, then the interaction terms to be considered simultaneously should be PCW and ERP on the one hand, and ERP and SCM (or CRM) on the other hand. In this manner, a regression analysis can capture the role of the intensity of ICT use as a determinant to adopt ERP system and, subsequently, provided that ERP systems were adopted successfully, the impact of SCM or CRM should be conditional on the adoption of ERP. This hypothesis is tested in column 6.

The result presented in column 6 shows that, indeed, the impact of ICT not only depends on the introduction of ICT applications, but the complementarity between ICT components is a determinant of firm heterogeneity. This is highlighted by the significant coefficient of the interaction terms of PCW and ERP, and ERP and SCM (coeff: 0.19, std. error: 0.10 and coeff: 0.13 , std. error: 0.07 , respectively). Moreover, the observed complementarity is consistent with the previous argument suggesting that such complementarities depend on the characteristics of the considered applications (e.g. timing of adoption). Note again that if ICT is not used intensively, the marginal effect of the particular ICT applications on firm heterogeneity is negative.

In sum, the results of Table 4 show that ICT affects firm heterogeneity only when ICT is used intensively and jointly with particular ICT applications. These results are robust to nonparametric specifications. If ICT impacts productivity positively and induces heterogeneity, it can be argued that ICT represent a source of volatility that stimulates the process of creative destruction. If this is the case, firm strategies should react accordingly, specially strategies that can provide a competitive advantage such as R\&D initiatives. This is analyzed in Table 5 for a subsample of firms that reported ICT consulting activities in 2003. This selection was performed in order to consider firms for which ICT infrastructure is important. Table 6 shows that the value and significance level of the coefficients using the full sample are very 
close to the values reported in Table 5. However, the specification tests are inconclusive.

Table 5 presents the main results of the analysis and performs the two stage approach taken into account the specification presented in column 4 of Table 4 . Column 1 presents the benchmark case considering an OLS specification. Following a instrumental variable approach, column 2 considers the impact of firm heterogeneity on R\&D incentives where ICT variables act as instruments. Column 2 shows a positive impact of ICT induced heterogeneity on the fraction of employees that perform R\&D (coeff: 0.06, std. error: 0.03). The reported p-values of the endogeneity and overidentification tests ( 0.10 and 0.83 , respectively) suggest the validity of the IV approach and the exclusion restriction for the considered firms. In order to verify the robustness of this result, column 3 and 4 consider a Tobit and IV Tobit specification due to the censoring present in the R\&D information. Interestingly, the results are maintained, including the required specification tests.

In order to account for the parametric shortcomings associated with the estimations of Tobit models, column 5 presents the results of a semiparametric model proposed by Blundell and Powell (2007). This approach accounts for censoring and endogenous regressors in a semiparametric setting (nonparametric first stage). Interestingly, the impact is still present although its magnitude is clearly reduced. These results suggest that firm heterogeneity is a factor explaining firms' strategic decisions and that ICT exert an important and independent impact in generating such heterogeneity.

\section{Robustness Checks}

This section presents some alternative specifications in order to check the robustness of the main results. In particular, two different alternative specification of the two stage procedure were investigated. First, the specifications presented in Table 5 were estimated for the whole available sample and not only for firms that reported ICT consulting activities in 2003, revealing the importance of ICT infrastructure in their operations. The results are presented in Table 6. Second, alternative measures of innovations were also taken into account under the same first stage specification. The alternative innovation measures correspond to the percentage of sales reported in 2006 that are derived from the product innovations introduced during the period 2004-2006, as well as the percentage of cost reductions achieved in 2006 from the introduction of process innovations during the period 2004-2006. 
Consistent with the results reported in Table 5, Table 6 shows that the main results with respect to the impact of ICT induced heterogeneity on the ratio of R\&D employees and total employees are maintained when the full sample is considered for the parametric approaches presented in columns 1-4. Although the endogeneity tests suggest the validity of the two stage approach, the overidentification tests are inconclusive in the IV GMM and IV Tobit specifications presented in columns 2 and 4 of Table 6 (i.e. rejection is achieved only at 10\%, while in Table 5 no rejection was possible). Within the analysis of this paper, rejection of the overidentification test implies that the use of ICT does independently affect R\&D incentives, as well as firm heterogeneity. If rejection is achieved with high confidence, which is not the case in the present analysis, the proposed two stage approach would be invalid.

In addition, instead of analyzing the impact of ICT induced heterogeneity on R\&D incentives, the analysis also considers the impact on the percentage of sales reported in 2006 that are derived from the product innovations introduced during the period 2004-2006 as a measure of innovative output. As the analysis presented in Table 5, the sample used corresponds only to firms that reported ICT consulting activities in 2003 in order to consider the impact of ICT induced heterogeneity on ICT intensive firms. In this case, the coefficients of the parametric specifications were significant although the specification test rejected the validity of the approach. This result is not surprising given the demand side factors (not considered in the analysis) that might affect the relationship between firm heterogeneity and the benefits of product innovation.

Similarly, the analysis also considers the case of a different measure of innovative output. In this case, the percentage of cost reductions achieved in 2006 from the introduction of process innovations during the period 2004-2006 was investigated. As before, the analysis was performed for ICT intensive firms. The parametric results are consistent with the main results of the paper reported in Table 5, including the specification tests. This result suggests that the adoption of ICT is a useful tool to differentiate a given firm from its competitors (i.e. first stage results are significant) and this ICT induced heterogeneity has an independent impact on the firm innovative output (i.e. second stage results).

\section{Conclusions}

This paper studies how the adoption of information and communication technologies (ICT) affects firm heterogeneity and thereby contributes to the productivity driven selection mech- 
anism that determines aggregate productivity growth within industries. Given the well documented existence of high and persistent productivity differences within industries where more productive firms grow faster, exhibit a higher probability of survival and displace low productivity firms, this paper attempts to specifically estimate the role of ICT on such firm heterogeneity. Moreover, to explore the role of ICT induced heterogeneity on the "creative destruction" process, the results are related to observed firm strategies relevant to that process (i.e. R\&D incentives and innovation outputs). The results show that ICT has a robust, positive impact on firm heterogeneity only when ICT is used intensively and jointly with specific ICT applications. In addition, the analysis showed that ICT induced heterogeneity is not innocuous: it has a significant and positive, albeit small, impact on the incentives to innovate. These results suggest that firm heterogeneity is a factor explaining firms' strategic decisions and that ICT exert an important and independent impact in generating such heterogeneity. 


\section{References}

Acemoglu, D., P. Aghion, F. Zilibotti, 2003, Distance to Frontier and Vertical Integration, Journal of the European Economic Association, 1, 630-38.

Acemoglu, D., P. Aghion, F. Zilibotti, 2006, Distance to Frontier, Selection, and Economic Growth, Journal of the European Economic Association, 4, 37-74.

Acemoglu D., Aghion P., Lelarge C., Van Reenen, J. and F. Zilibotti, 2007, Technology, Information, and the Decentralization of the Firm, Quarterly Journal of Economics, 122 (4), 1759-99.

Aghion, P., N. Bloom, R. Blundell, R. Griffith and P. Howitt, 2005, Competition and Innovation: An Inverted-U Relationship, Quarterly Journal of Economics, 120, 701728.

Aghion P. and R. Griffith, 2005, Competition and Innovation: Reconciling Theory and Evidence. Zeuthen Lectures. MIT Press.

Bartelsman, E. and M. Doms, 2000, Understanding Productivity: Lessons from Longitudinal Microdata, Journal of Economic Literature, 38 (3), 569-94.

Bartelsman, E., J. Haskel and R. Martin, 2006, Distance to Which Frontier? Evidence on Productivity Convergence from International Firm-Level Data, Working Paper, University of Amsterdam.

Bloom, N., R. Sadun and J. Van Reenen, 2008, Americans do IT Better: US Multinational and the Productivity Miracle, Working Paper, Stanford University.

Blundell R. and J. Powell, 2007, Censored Regression Quantiles with Endogenous Regressors, Journal of Econometrics, 141, 65-83.

Bresnahan, T., E. Brynjolfsson and L. Hitt, 2002, Information Technology, Workplace Organization and the Demand for Skilled Labor: Firm-Level Evidence, Quarterly Journal of Economics, 117, 1, 339-76.

Brynjolfsson, E. and L. Hitt, 2003, Computing Productivity: Firm Level Evidence, Review of Economics and Statistics, 85, 4, 793-808.

Chun H., J. Kim, R. Morck, B. Yeung, 2008, Creative Destruction and Firm-specific Performance Heterogeneity, Journal of Financial Economics, 89, 109-35. 
Crepon, B., E. Duguet and J. Mairesse, 1998, Research, Innovation and Productivity: An Econometric Analysis at the Firm Level, Economics of Innovation and New Technology, $7(2), 115-58$.

Draca, M., R. Sadun and J. Van Reenen, 2007, Productivity and ICT: A Review of the Evidence, In Mansell, R., C. Avgerou, D. Quah and R. Silverstone (Eds.), The Oxford Handbook of Information and Communication Technologies, Oxford.

Foster, L., J. Haltiwanger and C. Syverson, 2008, Reallocation, Firm Turnover, and Efficiency: Selection on Productivity or Profitability?, American Economic Review, 98 (1), 394-425.

Griliches, Z., 1995, R\&D and Productivity: Econometric Results and Measurement Issues, in Stoneman, P. (Ed.), Handbook of the Economics of Innovation and Technological Change, Oxford, 52-89.

Hall, B., F. Lotti and J. Mairesse, 2008, Innovation and Productivity in SMES: Empirical Evidence for Italy, NBER Working Paper No. 14594.

Jorgenson, D., M. Ho and K. Stiroh, 2008, A Retrospective Look at the U.S Productivity Growth Resurgence, Journal of Economic Perspectives. 22, 1, 3-24.

Li, Q. and J. S. Racine, 2007, Nonparametric Econometrics: Theory and Practice, Princeton University Press, Princeton.

Syverson, C., 2004, Product Substitutability and Productivity Dispersion, Review of Economics and Statistics, 86 (4), 534-550.

Van Ark, B., M. Timmer and M. O'Mahoney, 2008, The Productivity Gap Between Europe and the United States: Trends and Causes, Journal of Economic Perspectives, 22, 1, $25-44$. 


\section{Appendix A: Blundell and Powell (2007)}

The previous analysis included a semiparametric estimator proposed by Blundell and Powell (2007). This estimator takes simultaneously into account the presence of censoring in the dependent variable, as well as the existence of endogenous variables. The proposed estimator follows a two-stage approach, which estimates the censored model:

$$
y_{i}=\max \left(0, x_{i}^{\prime} \beta_{0}+u_{i}\right)
$$

The variable $x_{i}^{\prime}$ contains a set of regressors including an endogenous regressor, as well as an scalar error term $u_{i}$. The endogenous regressor can be represented as a possibly nonparametric function of its instruments $z_{i}$ and its corresponding error term $v_{i}$ :

$$
x_{i}^{(e)}=\pi\left(z_{i}\right)+v_{i}
$$

The estimation procedure follows in two stages. First, the conditional quantile $q_{i} \equiv Q_{i}\left[y_{i} \mid x_{i}, z_{i}\right]$ of the dependent variables is estimated used a nonparametric quantile regression (See Appendix $\mathrm{B}$ ). In the same stage, a control variable $v_{i}$ corresponding to the error of the nonparametric estimation of the endogenous regressor $v_{i}=x_{i}^{(e)}-\pi\left(z_{i}\right)$ is derived (See Appendix B). Subsequently, in a second stage the coefficients for $\beta_{i}$ are derived in a weighted least-squares regression following a "pairwise differencing" argument. The estimator is given by:

$$
\beta_{i}^{(e)}=\frac{\sum_{i<j} K_{v}\left(\frac{\hat{v_{i}}-\hat{v_{j}}}{h_{n}}\right) \cdot \hat{t_{i}} \hat{t_{j}}\left(x_{i}-x_{j}\right) \cdot\left(\hat{q_{i}}-\hat{q_{j}}\right)}{\sum_{i<j} K_{v}\left(\frac{\hat{v_{i}}-\hat{v_{j}}}{h_{n}}\right) \cdot \hat{t_{i}} \hat{t_{j}}\left(x_{i}-x_{j}\right) \cdot\left(x_{i}-x_{j}\right)^{\prime}}
$$

The variable $K_{v}$ is the kernel function chosen. In this paper, an Epanechikov kernel was employed. The term $h_{n}$ corresponds to the optimized bandwidth derived by a cross-validation method and $t_{i}$ represents a trimming term ensuring that censoring is taken into account. Standard Errors are derived by bootstrapping with 500 iterations. 


\section{Appendix B: Multinominal Kernel regression}

Estimation of the nonparametric kernel regression and nonparametric quantile regression are described in Li and Racine (2007). Both procedures used kernel estimations with mixed data continuous and categorical data to allow the use of discrete regressors. Importantly, bandwidths for the smoothing parameters are derived by data driven cross-validation methods.

\section{Nonparametric Kernel regression}

$\mathrm{Li}$ and Racine (2007) propose a method for nonparametric regression that includes both, continuous and discrete regressors. They apply a kernel method based on work of Aitchison and Aitkens (1976). The nonparametric function consider is:

$$
Y i=g\left(X_{i}\right)+u_{i}
$$

The vector $X_{i}=\left(X_{c}, X_{d}\right)$ contains continuous, as well as discrete variables. The modified kernel estimator $K_{h, i x}=\left(W_{h, i x} L_{\lambda, i x}\right)$ contains an estimator for each, continuous variables $W_{h, i x}$ and discrete variables $L_{\lambda, i x}$. The resulting kernel function for both variables is defined as:

$$
K_{h, i x}=\frac{1}{n} \sum W_{h 0}\left(\frac{\left(X_{i}^{c}-x^{c}\right)}{h}\right) \cdot L\left(X_{i}^{d}, x^{d}, \lambda\right)
$$

with $h$ and $\lambda \varepsilon[0, c-1 / c]$ being non-stochastic smoothing parameter that are derived by a cross-validation bandwidth estimation. $W_{h 0}$ is a kernel function for continuous variables and $L\left(X_{i}^{d}, x^{d}, \lambda\right)$ for discrete variables. The continuous kernel can contain any usual kernel available for continuous data (i.e. Epanechikov or Gaussian), while for discrete variables is Aitchisons and Aitkens (1976). 


$$
\bar{l}\left(\bar{X}_{i}^{d}, \bar{x}_{i}^{d}\right)= \begin{cases}1-\lambda, & \text { if } \bar{X}_{i}^{d}=\bar{x}_{i}^{d} \\ \frac{\lambda}{c-1}, & \text { otherwise }\end{cases}
$$

The resulting Kernel estimator for both kinds of variables, the joint density function of $\left(X_{c}, X_{d}\right)$, is therefore:

$$
\hat{f}(x)=\frac{1}{n} \sum K_{h, i x}
$$

Estimation of $\hat{g_{x}}$ is accounting for the joint density function and derived easily by:

$$
\hat{g_{x}}=y \frac{\hat{f}(y, x)}{\hat{f}(x) d y}=\frac{n^{-1} \sum Y_{i} K_{h, i x}}{\hat{f}_{(}(x)}
$$

\section{Nonparametric quantile estimation}

$\mathrm{Li}$ and Racine (2007) provide an estimator to derive conditional cumulative distribution function $(\mathrm{CDF})$ nonparametrically by a kernel estimator and to determine the conditional quantile of a function of continuous and dichotomous regressors. Estimation uses the same kernel function as in the nonparametric kernel regression also provided by Li and Racine (2007). In a first step, the conditional cumulative distribution function (CDF) of $Y$ is estimated:

$$
\hat{F}(y, x)=\frac{n^{-1} \sum G\left(\frac{y-Y_{i}}{h_{0}}\right) K_{h}\left(X_{i}, x\right)}{\hat{f}_{x}}
$$

Importantly, $G$ is a kernel chosen to smooth $Y_{i}$. After estimation of the CDF the conditional quantile is given by the inverted conditional CDF. Therefore:

$$
\hat{q}_{\alpha}(x)=\inf \{y: F(y \mid x) \geq \alpha\} \equiv \hat{F}^{-1}(\alpha \mid x)
$$


In practice, $\hat{q}_{\alpha}(x)$ is derived by computation of the following objective function, minimizing $q:$

$$
\hat{q}_{\alpha}(x)=\arg \min _{q} \mid \alpha-\hat{F}(q \mid x)
$$




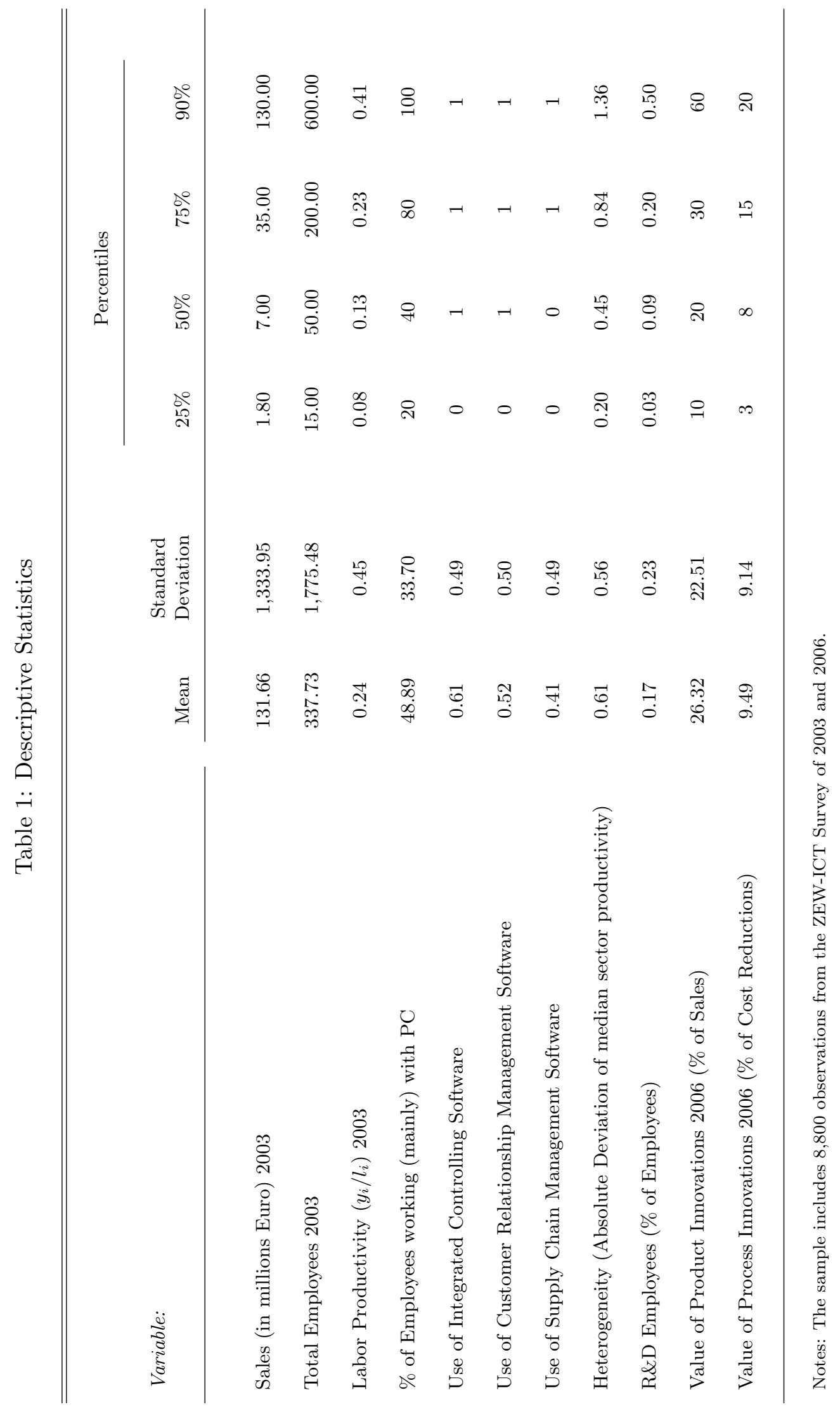




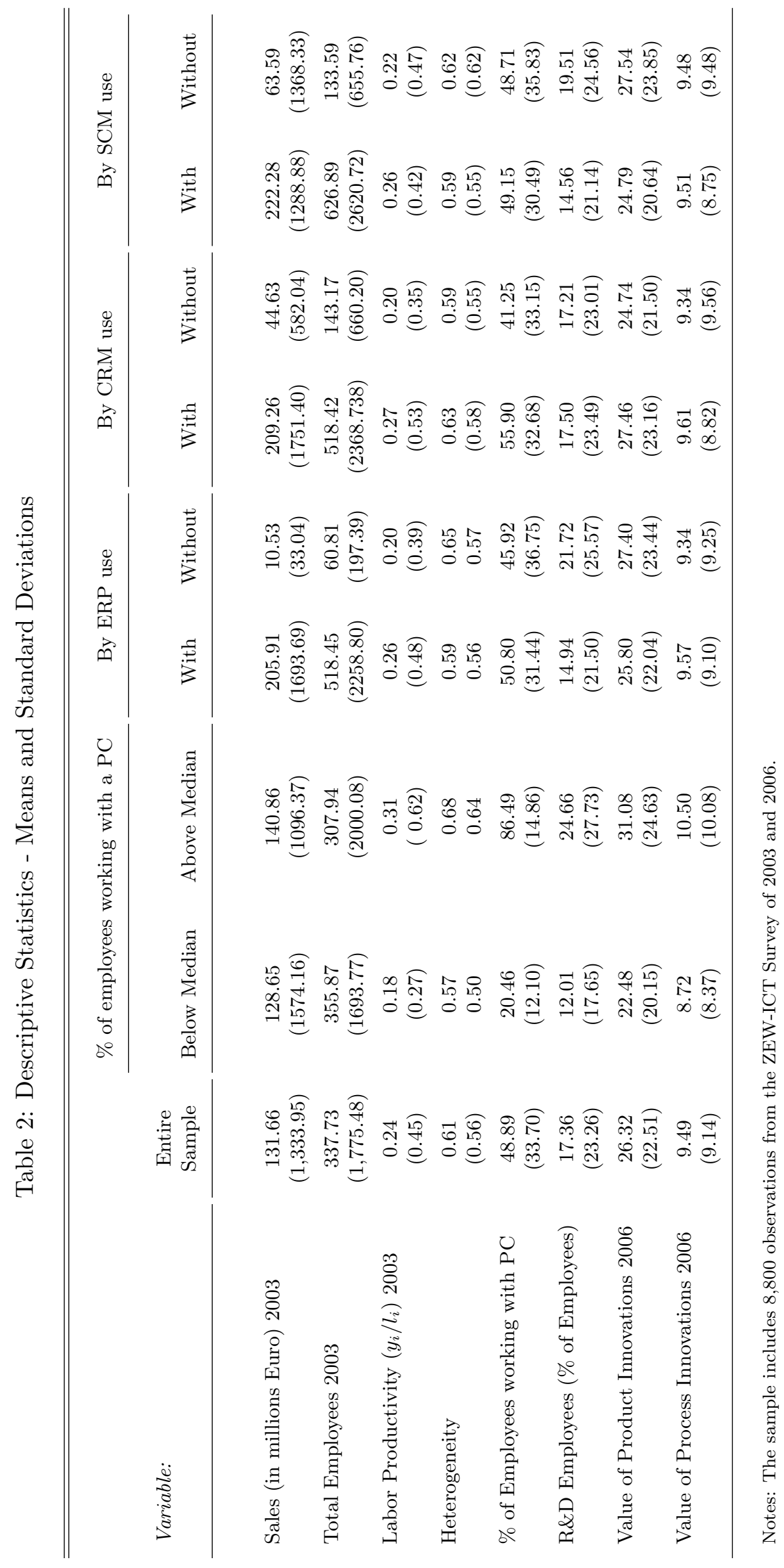


Table 3: Quantile Regression: The Impact of ICT on Firm-Specific Deviation

\begin{tabular}{|c|c|c|c|c|c|}
\hline \multicolumn{6}{|c|}{ Quantile Regression } \\
\hline & $\begin{array}{l}15 \text { th } \\
(1)\end{array}$ & $\begin{array}{l}25 \text { th } \\
(2)\end{array}$ & $\begin{array}{l}50 \text { th } \\
(3)\end{array}$ & $\begin{array}{c}75 \text { th } \\
(4)\end{array}$ & $\begin{array}{c}85 \text { th } \\
(5)\end{array}$ \\
\hline Labor 2003 & $\begin{array}{l}-0.0024 \\
(0.0177)\end{array}$ & $\begin{array}{c}-0.0246^{*} \\
(0.0149)\end{array}$ & $\begin{array}{c}-0.0257^{* *} \\
(0.0120)\end{array}$ & $\begin{array}{c}-0.0527^{* * *} \\
(0.0147)\end{array}$ & $\begin{array}{c}-0.0647^{* * *} \\
(0.0187)\end{array}$ \\
\hline Firm Age & $\begin{array}{c}0.0012 \\
(0.0012)\end{array}$ & $\begin{array}{c}0.0010 \\
(0.0009)\end{array}$ & $\begin{array}{c}0.0000 \\
(0.0008)\end{array}$ & $\begin{array}{l}-0.0000 \\
(0.0010)\end{array}$ & $\begin{array}{l}-0.0007 \\
(0.0010)\end{array}$ \\
\hline$\%$ of Employees working with $\mathrm{PC}(P C W)$ & $\begin{array}{c}-0.1462 \\
(0.1399)\end{array}$ & $\begin{array}{c}-0.1922^{*} \\
(0.1098)\end{array}$ & $\begin{array}{c}-0.3200^{* * *} \\
(0.1023)\end{array}$ & $\begin{array}{c}-0.4883^{* * *} \\
(0.1045)\end{array}$ & $\begin{array}{c}-0.4924^{* * *} \\
(0.1232)\end{array}$ \\
\hline Integrated Controlling Solutions $(E R P)$ & $\begin{array}{l}-0.0523 \\
(0.0777)\end{array}$ & $\begin{array}{l}-0.0312 \\
(0.0754)\end{array}$ & $\begin{array}{c}-0.1503^{* *} \\
(0.0667)\end{array}$ & $\begin{array}{c}-0.1989^{* * *} \\
(0.0744)\end{array}$ & $\begin{array}{c}-0.2629^{* * *} \\
(0.0954)\end{array}$ \\
\hline$P C W \times E R P$ & $\begin{array}{l}-0.0841 \\
0.1422)\end{array}$ & $\begin{array}{l}-0.0704 \\
(0.1376)\end{array}$ & $\begin{array}{c}0.1034 \\
(0.1110)\end{array}$ & $\begin{array}{c}0.2786^{* *} \\
(0.1099)\end{array}$ & $\begin{array}{c}0.3154^{* *} \\
(0.1440)\end{array}$ \\
\hline 1st Quartile (Labor Productivity) & $\begin{array}{c}1.498^{* * *} * \\
(0.0959)\end{array}$ & $\begin{array}{c}1.3820^{* * *} \\
(0.0810)\end{array}$ & $\begin{array}{c}1.1158^{* * *} \\
(0.0654)\end{array}$ & $\begin{array}{c}0.7463^{* * *} \\
(0.0758)\end{array}$ & $\begin{array}{c}0.5678^{* * *} \\
(0.0760)\end{array}$ \\
\hline 2nd Quartile & $\begin{array}{c}1.1911^{* * *} \\
(0.0826)\end{array}$ & $\begin{array}{c}1.044^{* * *} \\
(0.0725)\end{array}$ & $\begin{array}{c}0.7477^{* * *} \\
(0.0597)\end{array}$ & $\begin{array}{c}0.3483^{* * *} \\
(0.0682)\end{array}$ & $\begin{array}{c}0.1572^{* *} \\
(0.0702)\end{array}$ \\
\hline 3rd Quartile & $\begin{array}{c}0.8450^{* * *} \\
(0.0836)\end{array}$ & $\begin{array}{c}0.7112^{* * *} \\
(0.0757)\end{array}$ & $\begin{array}{c}0.4303^{* * *} \\
(0.0592)\end{array}$ & $\begin{array}{c}0.1197^{*} \\
(0.0745)\end{array}$ & $\begin{array}{c}-0.04673 \\
(0.0736)\end{array}$ \\
\hline Constant & $\begin{array}{c}-1.287^{* * *} \\
(0.1522)\end{array}$ & $\begin{array}{c}-0.9623^{* * *} \\
(0.1226)\end{array}$ & $\begin{array}{c}-0.3302^{* * *} \\
(0.0964)\end{array}$ & $\begin{array}{c}0.4510^{* * *} \\
(0.1315)\end{array}$ & $\begin{array}{c}1.0013^{* * *} \\
(0.1774)\end{array}$ \\
\hline Number of Observations & 1251 & 1251 & 1251 & 1251 & 1251 \\
\hline Pseudo- $R^{2}$ & 0.3112 & 0.2856 & 0.2344 & 0.2038 & 0.1967 \\
\hline
\end{tabular}

Bootstrapped standard errors with 400 replications are reported in parenthesis.

Industry dummies, location and exporting behavior included.

*** Significant at $1 \%$.** Significant at $5 \%$. * Significant at $10 \%$. 
Table 4: Impact of ICT on Firm-Specific Heterogeneity

\begin{tabular}{|c|c|c|c|c|c|c|}
\hline \multirow{2}{*}{$\begin{array}{l}\text { Dependent Variable: } \\
\text { Firm Heterogeneity } \\
\text { (Absolute deviation from Median } \\
\text { of Labor Productivity } 2006 \text { (in Logs.)) }\end{array}$} & \multicolumn{6}{|c|}{ Ordinary Least Squares } \\
\hline & (1) & $(2)$ & $(3)$ & $(4)$ & $(5)$ & $(6)$ \\
\hline Labor 2003 & $\begin{array}{c}0.0033 \\
(0.0108)\end{array}$ & $\begin{array}{c}0.0015 \\
(0.0098)\end{array}$ & $\begin{array}{c}0.0058 \\
(0.0117)\end{array}$ & $\begin{array}{c}0.0073 \\
(0.0117)\end{array}$ & $\begin{array}{c}0.0063 \\
(0.0117)\end{array}$ & $\begin{array}{c}0.0055 \\
(0.0117)\end{array}$ \\
\hline Firm Age & $\begin{array}{l}-0.0010 \\
(0.0010)\end{array}$ & $\begin{array}{l}-0.0010 \\
(0.0010)\end{array}$ & $\begin{array}{l}-0.0010 \\
(0.0010)\end{array}$ & $\begin{array}{l}-0.0010 \\
(0.0010)\end{array}$ & $\begin{array}{l}-0.0010 \\
(0.0010)\end{array}$ & $\begin{array}{l}-0.0009 \\
(0.0010)\end{array}$ \\
\hline$\%$ of Employees working with $\mathrm{PC}(P C W)$ & $\begin{array}{c}0.1074 \\
(0.0668)\end{array}$ & $\begin{array}{c}0.0315 \\
(0.0610)\end{array}$ & $\begin{array}{c}0.0396 \\
(0.0616)\end{array}$ & $\begin{array}{l}-0.0650 \\
(0.0832)\end{array}$ & $\begin{array}{c}0.0101 \\
(0.0709)\end{array}$ & $\begin{array}{l}-0.0635 \\
(0.0831)\end{array}$ \\
\hline Enterprise Resource Planning $(E R P))$ & & & $\begin{array}{c}-0.0203 \\
(0.0370)\end{array}$ & $\begin{array}{c}-0.1077^{* *} \\
(0.0536)\end{array}$ & $\begin{array}{c}-0.0189 \\
(0.0371)\end{array}$ & $\begin{array}{c}-0.1424^{* *} \\
(0.0572)\end{array}$ \\
\hline Supply Chain Management $(S C M)$ & & & $\begin{array}{l}-0.0172 \\
(0.0325)\end{array}$ & $\begin{array}{l}-0.0145 \\
(0.0324)\end{array}$ & $\begin{array}{c}-0.0574 \\
(0.0515)\end{array}$ & $\begin{array}{c}-0.1051^{*} \\
(0.0557)\end{array}$ \\
\hline$P C W \times S C M$ & & & & & $\begin{array}{c}0.0865 \\
(0.0985)\end{array}$ & \\
\hline$P C W \times E R P$ & & & & $\begin{array}{c}0.1893^{*} \\
(0.0976)\end{array}$ & & $\begin{array}{c}0.1869^{*} \\
(0.0974)\end{array}$ \\
\hline$E R P \times S C M$ & & & & & & $\begin{array}{c}0.1283^{* *} \\
(0.0654)\end{array}$ \\
\hline 1st Quartile (Labor Productivity) & & $\begin{array}{c}-0.2499^{* * *} \\
(0.0454)\end{array}$ & $\begin{array}{c}-0.2522^{* * *} \\
(0.0455)\end{array}$ & $\begin{array}{c}-0.2562^{* * *} \\
(0.0455)\end{array}$ & $\begin{array}{c}-0.2519^{* * *} \\
(0.0455)\end{array}$ & $\begin{array}{c}-0.2555^{* * *} \\
(0.0455)\end{array}$ \\
\hline 2nd Quartile & & $\begin{array}{c}-0.5423^{* * *} \\
(0.0426)\end{array}$ & $\begin{array}{c}-0.5439^{* * *} \\
(0.0425)\end{array}$ & $\begin{array}{c}-0.5416^{* * *} \\
(0.0426)\end{array}$ & $\begin{array}{c}-0.5402^{* * *} \\
(0.0428)\end{array}$ & $\begin{array}{c}-0.5405^{* * *} \\
(0.0426)\end{array}$ \\
\hline 3rd Quartile & & $\begin{array}{c}-0.4371^{* * *} \\
(0.0443)\end{array}$ & $\begin{array}{c}-0.4357^{* * *} \\
(0.0444)\end{array}$ & $\begin{array}{c}-0.4345^{* * *} \\
(0.0443)\end{array}$ & $\begin{array}{c}-0.4339^{* * *} \\
(0.0446)\end{array}$ & $\begin{array}{c}-0.4352^{* * *} \\
(0.0444)\end{array}$ \\
\hline Constant & $\begin{array}{c}0.6819 * * * \\
(0.0763)\end{array}$ & $\begin{array}{c}0.9892^{* * *} \\
(0.0808)\end{array}$ & $\begin{array}{c}0.9856^{* * *} \\
(0.0816)\end{array}$ & $\begin{array}{c}1.0225^{* * *} \\
(0.0831)\end{array}$ & $\begin{array}{c}0.9949 * * * \\
(0.0817)\end{array}$ & $\begin{array}{c}0.2973 \\
(0.1915)\end{array}$ \\
\hline Number of Observations & 1251 & 1251 & 1251 & 1251 & 1251 & 1251 \\
\hline F-statistic & 2.62 & 11.67 & 10.75 & 10.54 & 10.37 & 10.60 \\
\hline$R^{2}$ & 0.0490 & 0.1882 & 0.1877 & 0.1914 & 0.1892 & 0.1935 \\
\hline
\end{tabular}


Table 5: Impact of Firm-Specific Heterogeneity on R\&D Intensity - ICT Intensive Firms

\begin{tabular}{|c|c|c|c|c|c|}
\hline & $\begin{array}{l}\text { OLS } \\
(1)\end{array}$ & $\begin{array}{l}\text { IV GMM } \\
\qquad(2)\end{array}$ & $\begin{array}{c}\text { Tobit } \\
(3)\end{array}$ & $\begin{array}{l}\text { IV Tobit } \\
\text { (4) }\end{array}$ & $\begin{array}{c}\text { Censored } \\
\text { Semiparametric } \\
(5)\end{array}$ \\
\hline \multicolumn{6}{|l|}{$\begin{array}{l}\text { First Stage } \\
\text { (Dep. Var.: Firm Heterogeneity 2006) }\end{array}$} \\
\hline$\%$ of Employees working with $\mathrm{PC}(P C W)$ & & $\begin{array}{l}-0.0872 \\
(0.1935)\end{array}$ & & $\begin{array}{l}-0.0872 \\
(0.1566)\end{array}$ & $\begin{array}{c}0.0000 \\
(0.3033)\end{array}$ \\
\hline Integrated Controlling Solutions $(E R P)$ & & $\begin{array}{l}-0.1971^{* *} \\
(0.0992)\end{array}$ & & $\begin{array}{l}-0.1971^{* *} \\
(0.0938)\end{array}$ & $\begin{array}{c}0.0000 \\
(0.4912)\end{array}$ \\
\hline$P C W \times E R P$ & & $\begin{array}{c}0.3387^{*} \\
(0.1986)\end{array}$ & & $\begin{array}{l}0.3387^{* *} \\
(0.1703)\end{array}$ & $\begin{array}{c}0.0405^{*} \\
(0.0175)\end{array}$ \\
\hline Labor 2003 (in Logs.) & & $\begin{array}{c}0.0052 \\
(0.0155)\end{array}$ & & $\begin{array}{c}0.0052 \\
(0.0158)\end{array}$ & \\
\hline Firm Age & & $\begin{array}{l}-0.0023^{* *} \\
(0.0010)\end{array}$ & & $\begin{array}{l}-0.0023^{* *} \\
(0.0011)\end{array}$ & \\
\hline 1st Quartile (Labor Productivity) & & $\begin{array}{l}-0.2637^{* * *} \\
(0.0738)\end{array}$ & & $\begin{array}{l}-0.2637^{* * *} \\
(0.0692)\end{array}$ & $\begin{array}{l}-0.0431^{* * *} \\
(0.0000)\end{array}$ \\
\hline 2nd Quartile & & $\begin{array}{l}-0.5740^{* * *} \\
(0.0603)\end{array}$ & & $\begin{array}{l}-0.5740^{* * *} \\
(0.0602)\end{array}$ & $\begin{array}{l}-0.1442^{* * *} \\
(0.0000)\end{array}$ \\
\hline 3rd Quartile & & $\begin{array}{l}-0.4519^{* * *} \\
(0.0631)\end{array}$ & & $\begin{array}{l}-0.4519^{* * *} \\
(0.0587)\end{array}$ & $\begin{array}{l}-0.1148^{* * *} \\
(0.0000)\end{array}$ \\
\hline
\end{tabular}

\section{Second Stage}

(Dep. Var.: R\&D Intensity 2006)

\begin{tabular}{|c|c|c|c|c|c|}
\hline Firm Heterogeneity (2006) & $\begin{array}{c}0.0130 \\
(0.0162)\end{array}$ & $\begin{array}{c}0.0628^{*} \\
(0.0334)\end{array}$ & $\begin{array}{c}0.0141 \\
(0.0159)\end{array}$ & $\begin{array}{c}0.0720^{* *} \\
(0.0352)\end{array}$ & $\begin{array}{l}0.0026^{* * *} \\
(0.0009)\end{array}$ \\
\hline Labor 2003 (in Logs.) & $\begin{array}{l}-0.0402^{* * *} \\
(0.0069)\end{array}$ & $\begin{array}{l}-0.0388^{* * *} \\
(0.0067)\end{array}$ & $\begin{array}{l}-0.0406^{* * *} \\
(0.0056)\end{array}$ & $\begin{array}{l}-0.0402^{* * *} \\
(0.0057)\end{array}$ & $\begin{array}{l}-0.2219^{* * *} \\
(0.0044)\end{array}$ \\
\hline Product Innovation & $\begin{array}{c}0.0437^{* *} \\
(0.0192)\end{array}$ & $\begin{array}{l}0.0416^{* *} \\
(0.0195)\end{array}$ & $\begin{array}{c}0.0509^{* *} \\
(0.0211)\end{array}$ & $\begin{array}{c}0.0475^{* *} \\
(0.0214)\end{array}$ & $\begin{array}{l}0.0033^{* * *} \\
(0.0005)\end{array}$ \\
\hline Firm Age & $\begin{array}{c}0.0009^{* *} \\
(0.0004)\end{array}$ & $\begin{array}{l}0.0009^{* *} \\
(0.0004)\end{array}$ & $\begin{array}{c}0.0009^{* *} \\
(0.0004)\end{array}$ & $\begin{array}{c}0.0011^{* *} \\
(0.0004)\end{array}$ & $\begin{array}{l}-0.5311^{* * *} \\
(0.0277)\end{array}$ \\
\hline Number of Observations & 505 & 505 & 505 & 505 & 505 \\
\hline Hansen's J-Test (p-value) & & 0.83 & & & \\
\hline Hausman Test (p-value) & & 0.10 & & & \\
\hline Amemiya-Lee-Newey Test ( $\mathrm{p}$-value) & & & & 0.75 & \\
\hline Wald Test (p-value) & & & & 0.06 & \\
\hline
\end{tabular}

\footnotetext{
Robust standard errors are reported in parenthesis. Industry dummies, location and exporting behavior included. First stage in column 5 reports estimated gradients evaluated at the median of the explanatory variable. p-values from a significance tests are reported in parenthesis. Second stage estimations in column 5 are in thousands and are calculated from a subsample of the large data set after pairwise differencing. See Blundell and Powell (2007). For the second stage in column 5 bootstrapped standard errors with 500 replications are reported in parenthesis. *** Significant at $1 \% . * *$ Significant at $5 \%$. * Significant at $10 \%$.
} 
Table 6: Impact of Firm-Specific Heterogeneity on R\&D Intensity - Full Sample

\begin{tabular}{|c|c|c|c|c|c|}
\hline & $\begin{array}{l}\text { OLS } \\
(1)\end{array}$ & $\begin{array}{l}\text { IV GMM } \\
\text { (2) }\end{array}$ & $\begin{array}{r}\text { Tobit } \\
\text { (3) }\end{array}$ & $\begin{array}{l}\text { IV Tobit } \\
\text { (4) }\end{array}$ & $\begin{array}{c}\text { Censored } \\
\text { Semiparametric } \\
(5)\end{array}$ \\
\hline \multicolumn{6}{|l|}{$\begin{array}{l}\text { First Stage } \\
\text { (Dep. Var.: Firm Heterogeneity 2006) }\end{array}$} \\
\hline$\%$ of Employees working with PC $(P C W)$ & & $\begin{array}{l}-0.1242 \\
(0.1006)\end{array}$ & & $\begin{array}{l}-0.1242 \\
(0.0922)\end{array}$ & $\begin{array}{l}0.0012^{* * *} \\
(0.0000)\end{array}$ \\
\hline Integrated Controlling Solutions $(E R P)$ & & $\begin{array}{l}-0.1567^{* *} \\
(0.0631)\end{array}$ & & $\begin{array}{l}-0.1567^{* *} \\
(0.0651)\end{array}$ & $\begin{array}{l}-0.0025 \\
(0.1930)\end{array}$ \\
\hline$P C W \times E R P$ & & $\begin{array}{l}0.27361^{* *} \\
(0.1162)\end{array}$ & & $\begin{array}{l}0.2736^{* *} \\
(0.1070)\end{array}$ & $\begin{array}{c}0.0000 \\
(0.3634)\end{array}$ \\
\hline Labor 2003 (in Logs.) & & $\begin{array}{c}0.0069 \\
(0.0117)\end{array}$ & & $\begin{array}{c}0.0069 \\
(0.0122)\end{array}$ & \\
\hline Firm Age & & $\begin{array}{l}-0.0022^{* * *} \\
(0.0008)\end{array}$ & & $\begin{array}{l}-0.0022^{* *} \\
(0.0009)\end{array}$ & \\
\hline 1st Quartile (Labor Productivity) & & $\begin{array}{l}-0.2645^{* * *} \\
(0.0512)\end{array}$ & & $\begin{array}{l}-0.2645^{* * *} \\
(0.0501)\end{array}$ & $\begin{array}{l}-0.0485^{* * *} \\
(0.0000)\end{array}$ \\
\hline 2nd Quartile & & $\begin{array}{l}-0.5279^{* * *} \\
(0.0472)\end{array}$ & & $\begin{array}{l}-0.5279^{* * *} \\
(0.0447)\end{array}$ & $\begin{array}{l}-0.1404^{* * *} \\
(0.0000)\end{array}$ \\
\hline 3rd Quartile & & $\begin{array}{l}-0.4316^{* * *} \\
(0.0481)\end{array}$ & & $\begin{array}{l}-0.4316^{* * *} \\
(0.0460)\end{array}$ & $\begin{array}{l}-0.1026^{* * *} \\
(0.0000)\end{array}$ \\
\hline
\end{tabular}

\section{Second Stage}

(Dep. Var.: RGD Intensity 2006)

Firm Heterogeneity (2006)

$\begin{array}{lllll}-0.0076 & 0.0588^{*} & 0.0062 & 0.0497^{*} & 0.0005 \\ (0.0131) & (0.0304) & (0.0124) & (0.0306) & (0.0004) \\ -0.0490^{* * *} & -0.0466^{* * *} & -0.0497^{* * *} & -0.0497^{* * *} & -0.2647^{* * *} \\ (0.0051) & (0.0050) & (0.0045) & (0.0045) & (0.0046) \\ 0.0563^{* * *} & 0.0540^{* * *} & 0.0655^{* * *} & 0.0647^{* * *} & 0.0003 \\ (0.0142) & (0.0139) & (0.0163) & (0.0162) & (0.0004) \\ 0.0008^{* *} & 0.0009^{* *} & 0.0009^{* *} & 0.0010^{* *} & -0.6045^{* * *} \\ (0.0004) & (0.0004) & (0.0004) & (0.0004) & (0.0173)\end{array}$

Number of Observations

922

922

922

922

922

Hansen's J-Test (p-value)

0.09

Hausman Test (p-value)

0.09

Amemiya-Lee-Newey Test ( $\mathrm{p}$-value)

0.01

Wald Test ( $\mathrm{p}$-value)

0.12 